\title{
The Effect of Accounting Reservation in the Fairness of the Financial Statements in the Private Hospitals in Jordan
}

\author{
Dr. Ayman Saleh Mustafa Harb ${ }^{1}$ \\ 1 Department of Accounting - Faculty of Economics and Administrative Sciences, Assistant Professor (Zarqa \\ University - Jordan), P.O.Box ( 132222) - Zaraqa ( 13132) Jordan \\ Correspondence: Dr. Ayman Saleh Mustafa Harb, Department of Accounting - Faculty of Economics and \\ Administrative Sciences, Assistant Professor (Zarqa University - Jordan)
}

Received: October 2, 2017

Accepted: April 15, 2018

Online Published: April 16, 2018

doi:10.5430/afr.v7n2p194

URL: https://doi.org/10.5430/afr.v7n2p194

\begin{abstract}
This study aims at recognizing the effect of the accounting reservation in the fairness of the financial statements in the Private Hospitals in Jordan through determining the effect of the reservation in the accuracy of the financial statements in the private hospitals in Jordan.

For achieving these aims, the researcher designed a survey consisting of (24) paragraphs that were distributed upon the society of the study consisting of the private hospitals in Jordan and the number of these private hospitals is (24) in Amman, Zarqa and Irbid in the end of 2015.

This result indicates to the effect of the accounting reservation in the reliability of the financial statements in the private hospitals in Jordan.
\end{abstract}

Keywords: accounting reservation, the fairness of the financial statements, private hospitals

\section{The General Framework of the Study}

\subsection{Introduction}

The accounting reservation is considered as being one of the accounting policies followed in different sectors of business in the light of asserting from the fairness of the financial statements presented to the certain related parties. So, the accounting reservation based upon shall be conservatism and caution shall be taken into account, in addition to making sure of the safety and fairness of the financial statements.

The interest was increased by researchers in the matter of the accounting reservation in many years due to keeping the reliability of the accounting information stated in the final financial statements presented to the certain related parties in the establishment. The financial information existing in the financial reports are considered as being important for the investors in the processes of taking decisions; the decisions of expanding the investment processes and expanding in opening branches and other investing departments in the field of the sector in which the investor is executing his investment. The policies of the investors include considering the return for the risk in their investments as of reserving the profits and losses in the future decisions of their investments.

So, the accounting measurement, as per the procedures of the accounting reservation, has an important site within the traditional framework in order to prepare the financial statements. The impact of this policy reflects upon several applications in a clear way in the financial reports and upon the presented accounting information for being reached to the certain related parties having an accounting reliability and free of important errors and bias in order to be approved. This research tackled the private hospitals in Jordan in the position of the accounting reservation as researches in the field of the private hospitals are inconsiderable as of the accounting aspect.

\subsection{The Problem of the Study}

This study comes as a study on the subject of the impact of the accounting reservation in the fairness of accounting information on private hospitals in Jordan. 


\subsection{Elements of the Problem of the Study}

This study attempts to answer the following questions:

1. What is the effect of accounting reservation in the accuracy of the financial statements on the private hospitals in Jordan?

2. What is the effect of accounting reservation in the fairness of the financial statements on the private hospitals in Jordan?

\subsection{Research Importance}

The role of the accounting reservation in the accounting information in the private hospital sector in Jordan is of great importance in the fairness of the financial statements submitted by the accounting and financial departments and sections.

\subsection{Research Objective}

This study aims at to achieve a set of objectives, including:

1. Determine the effect of an accounting reservation in the accuracy of financial statements on private hospitals in Jordan.

2. Determine the effect of an accounting reservation in the fairness of financial statements on private hospitals in Jordan.

\subsection{Research Hypotheses}

In the study, the following hypotheses test:

\section{The First Hypothesis:}

HO: There is no significant effect determine the effect of an accounting reservation in the accuracy of financial statements in private hospitals in Jordan.

\subsection{The Second Hypothesis}

HO: There is no significant effect determine the effect of an accounting reservation in the fairness of financial statements in private hospitals in Jordan.

As for the variables of this study, there are three variables, divided into one independent variable and variables belonging two, is as follows:

A) The Independent Variable: (Accounting Reservation).

B) The dependent Variableis to:

\section{The Accuracy of Financial Statements.}

2. The Fairness of Financial Statements.

1.8 Here is a Sample of this Study

The Study Sample:

\section{Dependent Variables}

\section{Independent Variables}

\begin{tabular}{|c|}
\hline $\begin{array}{c}\text { The Accuracy of } \\
\text { Financial Statements }\end{array}$ \\
\hline $\begin{array}{c}\text { The Fairness of } \\
\text { Financial Statements }\end{array}$ \\
\hline
\end{tabular}

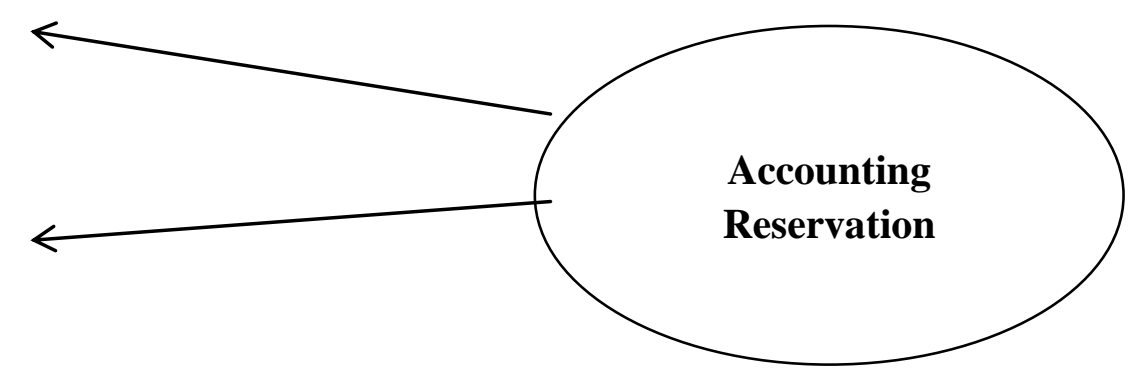




\section{Previous Studies}

Lafond and Watts (2008) study tackles the impact of the phenomena of the information asymmetry between managers and owners outside the establishment upon the prevailing of the reservation in the financial statements. The most important results of this study is the increase of the requirements of the investors towards the increase of the reservation upon measuring the accounting profit as a means for decreasing the problems of the agency. Chung and Wynn (2008) study assets that the motivation behind the accounting reservation is to avoid being exposed to the legal responsibility whether to the management of the company or the auditor. And there is no doubt that the legal responsibility and its results including the compensation in case of exaggerating the values of the profits and assets. And these values shall be greater in a significant way than in case of being reserved in an accounting way. The study concluded that there is a counter relationship among the costs charged by the company as a result of the legal responsibility. Ebaid (2010) study focused upon the previous studies in the field of the accounting reservation in the Kingdom of Saudi Arabia. It appeared that there is a general decrease in the degree of the accounting reservation in the financial reservation for the Saudi companies and this is what forms a great danger in the light of the importance of the accounting reservation. Hamdan (2011) study presents additional evidence about the level of the accounting reservation in the financial reports for the general Jordanian joint-stock companies. Also, this study, for the first time, sheds light on the relationship of the accounting reservation in improving the quality of the financial statements. The study concluded important indicators about the decrease of the level of the accounting reservation in the financial reports issued by the general Jordanian joint-stock industrial companies. Also, the study finds an important relationship in a statistical way between the accounting reservation and improving the quality of the financial reports through improving the opinion of the external auditor. Hamdan (2012) study aims at evaluating the level of the accounting reservation upon preparing the financial reports in the Jordanian companies. Furthermore, it discusses the factors influencing the level of the accounting reservation in such companies and such factors are about (the activity of the sector, the size of the companies and the indebtedness). The most important results of this study is that there is a decrease in the level of the accounting reservation in the financial reports issued by the Jordanian companies. Also, the study finds that bank are the most reserved in its accounting policies. In addition, the factor of the size had an influence in the level of the accounting reservation. Youssef (2012) study aims at testing the impact of the structure of the establishment ownership in reserving the financial reports as the analyses of the agency determines the nature of the administrative test for the accounting policies in the framework of the economic effects for such policies. Also, the accounting reservation forms one of the accounting principles which determines the characteristics of the presented accounting information and its role in tacking the decisions by different parties concerned with the establishment. The results show conformitywith the hypothesis stating that: the increase of the rate of the administrative ownership is associated with the rapprochement of the interests between the administration and the shareholders out of the administration. Abd Elmageed (2013) study aims at showing the measurement of the level of the accounting reservation and the factors affecting it in the annual financial reports for the insurance companies that are registered in the market of the financial statements in the Kingdom of Saudi Arabia during the period of (2008 to 2012). The study concluded that there is a law level of accounting reservation in the financial reports for the Saudi insurance companies. Furthermore, the study concluded that this level of the accounting reservation in such companies has a positive relationship with the size of the company and the ownership of the company and it has a negative relationship with the indebtedness of the company and the age of it. Saad Eldeen (2014) study focused upon the accounting reservation in increasing the authentication and the reliability of the financial statements. Also, it helps protecting the stakeholders in the establishment. The results of the study showed that there is a counter significant relationship between the degree of reserving the financial report and the cost of capital. Elkotayni and Aljumaili (2014) study aimed at trying to find advanced stages of predicting the financial failure in industrial companies in Amman financial market by measuring the level of being committed to the accounting reservation in companies, in addition to recognizing the relationship between the accounting reservation and the financial prediction. One of the most important results of such study was that there is a relationship between the accounting reservation and predicting the financial failure in the in industrial companies in Amman financial market. Al Najaer (2014) study aimed at measuring the level of the reservation in the financial reports issued by the general joint-stock companies listed in Palestine exchange, in addition to stating the effect of the accounting reservation upon the marketing value for the share. The results of the study showed the decrease of the level of the accounting reservation in the financial statements and reports issued by the Palestinian general joint-stock companies. Furthermore, the study found that the insurance sector and banks are the most reserved, while the investing sector is the least reserved and that the level of the accounting reservation affect negatively upon the marketing value of the share. Hussain (2015) study aimed at analyzing the relationship between the structure of the concentrated ownership and the conservative accounting in the financial statements and its relationship to the financial performance for the Egyptian 
companies restricted to the market of the financial statements. One of the most important results found by such study is that there is an accounting reservation in the Egyptian companies and it is an important mechanism keeping the survival of the companies in the market in the light of the political and economic conations though which it passed. Abujarad (2015) study aimed at stating the relationship between the reservation in the accounting policies and corporate governance and their impact on disclosure quality of the financial statements of local banks listed in Palestine exchange. The study concluded that there is a positive relationship of a statistical significance between the levels of the reservation of banks in their financial reports and its application to the rules of the corporate governance. Al-Sakini and Al-Awaweleh (2015) focused upon examining the effect of the accounting conservatism on the fair value in the Jordanian industrial corporations in the period from $(2006-2013)$. One of the most important results of such study is the difference of applying the accounting conservatism in the Jordanian industrial corporations and the results showed that there is an impact of the accounting conservatism on the fair value.

\subsection{The Expected Contribution from the Current Study}

The previous researches and studies focused upon the importance of the accounting reservation in the financial markets, ownership and the accounting policies, especially in presenting the data and reports in the investments in the financial markets. The current study shall be a new addition in the following subjects:

1. This study specializes with the accounting reservation and its relationship with the fairness of the financial statements.

2. This study linked the relationship between the accounting conservatism upon the sector of the private hospitals in Jordan.

\section{The Theoretical Framework of the Study}

\subsection{The Concept and the Importance of the Accounting Reservation}

Defined (Hanan, 2009) the accounting reservation by: having a doubt in the estimation due to the conditions of the non-assertion. There are several alternative ways for handling or measuring, so the accountant must prefer these solutions which lead to the net income or (the income statement) or to the book value for assets (the statement of the financial position) upon preparing the financial statements. Defined (Matar and others, 1996) the accounting reservation by: some of the elements of the financial statements which need to some estimation, especially the elements in which the personal guessing is involved. One aspect of the reservation and turning away from the exaggeration resulting from the optimism in handling some accounting matters must be taken into account. As defined (Suas, 1997) the accounting reservation by: not expecting the profits, but expecting all losses. And defined (Watts, 2008) the accounting reservation by: recognizing the expected losses not the expected profits and recognizing the minimum values for the assets.

The researcher agrees with the previous concepts and definitions for the accounting reservation that is about: the doubt in the estimation and recognition with the expected losses not the expected profits, in addition to focusing upon the losses more than the profits.

3.2 The Importance of the Accounting Reservation is Generally Confined to the Basic Components (Xin and Jaggi, 2014)

1. The differences in the information among manages, investors and other related parties shall be decreased.

2. The importance of the accounting reservation lies in the possibility of decreasing the accountability of the company management in a judicial way.

The researcher sees that the importance of the accounting reservation lies in decreasing the return that is subjected to the tax on the company through recognizing the return for being achieved.

Also, the researcher sees that the helpful information must be based upon reliability and it has the reliability if it is free of important errors and bias and that the user have the ability to depend upon it as being information expressing truly its meaning or what is expected to express.

\subsection{The Policy of the Accounting Reservation}

The accounting reservation reflects the situation of the accountant for handling the problem of the lack of assertion in a practical way that is to explain the ways of handling and solutions for such problems as follows: (Hanan, 2009, Page 238): 
1. A measurement that is related to the income statement through measuring the returns and profits in the minimum value and measuring the expenses and losses in the maximum value.

2. Measuring the income net in the minimum value among the possible ones.

3. A measurement that is related to the statement of the financial position through measuring the assets in the minimum value among the possible ones, measuring the obligations in the maximum value among the possible ones and measuring the rights of the ownership in the minimum value among the possible ones.

Furthermore, the researcher sees that applying the policy of the accounting reservation is to protect the parties of the establishments as the accounting reservation does not mean that the accountant intentionally decrease the returns, gains, assets and profits from one hand or increase the expenses, losses and obligations from another hand with no reason that can be approved from the accounting aspect.

As for the most important objections concerning the continuity in applying the accounting reservation are confined to: (Matar and others, 1996, Page 88):-

1- The accounting reservation shows sometimes a self-contradiction as it takes a pessimistic situation upon determining the income

2- The excessive pessimism by approving the minimum values for the assets and the maximum values for deductions as per the principle of the conservatism, in addition to not proving the profits that did be achieved by sale.

\subsection{The Accounting in the Sector of the Hospitals}

The hospitals are considered the most important service establishments in all countries; the health services are considered as being intangible goods involving all services which give the feeling of being satisfied with the health requirements whether being medical diagnosing services or therapeutic or several services. The hospitals are divided into two sections; governmental hospitals established by the state and private hospitals established by the individuals.

The hospital was defined by a committee of the experts of the international health for organizing the health care by: a main a part of the social and health organization, its role is to present the complete health care for citizens. Also, the hospital is considered as being a center for training those who are working in the field of health and conducting social and biological researches

The accounting in the private hospitals is based upon a group of principles that shall be applied in the sector of hospitals and the projects of the other business. These principles are associated with the accounting principles.

\section{Methods and Procedures}

\subsection{The Population and the Sample of the Study}

The population of the study consists of all the private hospitals in Jordan with the end of 2015. The private hospitals in Amman, Zarqa and Irbid were chosen. The society of the study includes (24) private hospitals in Amman, Zarqa and Irbid which gives a flexibility in searching for choosing the sample (the sample of the study). In addition, the unit of the analysis is about the individuals who are working in the private hospitals (they are $150,(150=\mathrm{N})$. The stratified sample for the society of the study includes (24) private hospital for Table of (1-6) and it lies in:- 


\begin{tabular}{llll}
\hline The Number & Hospital Name & Specialist & The Province \\
\hline 1 & Islamic & General & Amman \\
2 & Jordan & General & Amman \\
3 & The specialty & General & Amman \\
4 & Al khalidi & General & Amman \\
5 & Arab Medical Center & General & Amman \\
6 & Istiklal & General & Amman \\
7 & Consulting & General & Amman \\
8 & Al-Hayat & General & Amman \\
9 & Ibn Al-Haytham & General & Amman \\
10 & Jerusalem & General & Amman \\
11 & Shemesani & General & Amman \\
12 & Amman Surgical & General & Amman \\
13 & Luzmilla & General & Amman \\
14 & Al-Ahli & General & Amman \\
15 & Tlaa Al Ali & General & Amman \\
16 & Palestine & General & Amman \\
17 & Philadelphia & General & Amman \\
18 & Al-Bayader & General & Amman \\
19 & Jabal Al-Zaitoon & General & Zarqa \\
20 & Al-Hikma Modern & General & Zarqa \\
21 & Dleal & General & Zarqa \\
22 & Irbid Specialty & General & Irbid \\
23 & Irbid Islamic & General & Irbid \\
24 & Qawasemi & General & Irbid \\
\hline
\end{tabular}

The surveys shall be distributed upon the individuals who are working for the private hospitals; restricted to managers and heads of the private hospitals and upon the mangers and the heads of the accounting departments. The reason for choosing those individuals is that the belief of the researcher that such category of the individuals is the entity concerned in the subject of the study. So, the surveys shall be distributed upon the following categories:

1- The manager of the hospital or his deputy or assistant.

2- The financial managers.

3- The heads of accounting departments and accountants.

4- Accounting officers.

5- The managers or the heads of the internal auditing department (if any).

6- The heads of the information technology and computers departments.

The stratified sample shall be used. Through these groups chosen from the sample that forms the sample of the study, (150) surveys shall be distributed upon the individuals who are working for the private hospitals. As for the period of time of the society of the study, it was at the end of 31/12/2015.

\subsection{The Type of the Study}

This study is a descriptive, analytical and field one as it tests, analyses and describes the impact of the accounting reservation in the reliability and the fairness of the information in the private hospitals in Jordan.

\subsection{The Determinants of the Study}

The determinants of the study represents in:

1- The size of the chosen sample is about a stratified ample among specified terms for choosing the sample.

2- The lack of the references and previous studies about the subject of the study, especially in the field of hospitals sector. 
3- The samples working in Amman, Zarqa and Irbid were chosen.

\subsection{The Methods of Collecting Data}

The data were collected from secondary and primary sources and the personal experience of the researcher in the field of hospitals sector through methods of teaching and references and they were as follows:

\section{A) Secondary sources consisting of:}

1- The ready information that is available in libraries including books, references, courses and articles talking about the subject of the study and previous studies. And such information was depended upon in determining the theoretical framework of the study.

2- The annual reports issued about private hospitals in Jordan.

B) Primary Sources: they are represented in a survey that shall be distributed upon the individuals who are working in private hospitals in the sample of the study (that was mentioned before). The survey tackled all the aims of the research that were designed and distributed upon the individuals who are working in private hospitals.

The number of the distributed surveys (with the researcher) $=150$.

The number of the responses to the surveys (with the researcher) $=120$.

The number of the surveys that did not met the sample of the study $=30$.

It is fund that the percentage of the responses is equal to $(120+150=80 \%)$.

\subsection{The Statistical Methods}

For analyzing the data of the study, the researcher approved the statistical methods and the standard indicators. The most important used methods are:

A) The descriptive statistics, including:

1- The accounting average for stating how the paragraphs of the survey are important for the individuals of the sample.

2- The standard deviation for stating how the individuals of the sample are in agreement with each other and how the answers are close.

3- The percentage for stating the effect of these factors.

B) The Inferential statistics, including:

1- T-Test.

2- The multiple decline analysis.

Note: (SPSS) shall be taken for analyzing the data (Statistical Package for Social Sciences, SPSS).

4.6 Testing the Hypotheses of the Study

This part of the study represents analyzing the independent and affiliated variables and testing the hypotheses of the study as follows:-

Table no. (2-6_ represents the results of the stability of the accounting reservation fields in the fairness of the financial statements in the private hospitals in Jordan in the method of (Alpha Kronpakh) for the internal association:

\begin{tabular}{clcc}
\hline $\begin{array}{c}\text { The } \\
\text { Number }\end{array}$ & \multicolumn{1}{c}{ The Field } & $\begin{array}{c}\text { Number of } \\
\text { paragraphs }\end{array}$ & $\begin{array}{c}\text { Cronbach's } \\
\text { alpha value }\end{array}$ \\
\hline $\mathbf{1}$ & $\begin{array}{l}\text { The accounting reservation (the } \\
\text { independent variable) }\end{array}$ & 8 & $\mathbf{0 . 7 5 6}$ \\
2 & $\begin{array}{l}\text { The accuracy of the financial statements } \\
\text { (the first affiliated variable) } \\
\text { The fairness of the financial statements } \\
\text { (the second affiliated variable) } \\
\text { The survey as a whole }\end{array}$ & 8 & $\mathbf{0 . 6 2 9}$ \\
& $\mathbf{8}$ & $\mathbf{2 4}$ & $\mathbf{0 . 8 1 5}$ \\
\end{tabular}

The results of Table no. (2-6) indicate that the field of the value of Alpha Cronpakh for the internal association has a high degree of the accounting reservation in the fairness of the financial statements in the private hospitals in Jordan 
as the fields of the study as a whole reached $(0.890)$, the value of the stability reached $(0.756)$ for the accounting reservation (the independent variable), the field of the reliability of the financial statements reached (0.629) (the first affiliated variable) andthe field of the fairness of the financial statements reached (0.815) (the second affiliated variable). These values are considered as being suitable and adequate for the purposes of such study as all these values are very high indicating to suitable values of stability.

\subsection{Firstly: Analyzing the Variables}

\section{1- Analyzing the independent variable (the accounting reservation):}

The researcher conducted the analysis looking for finding the values of the accounting averages, the standard deviations and the relative importance for each paragraphs of the variables of the study as the researcher used the systematic measurement for describing the values of the accounting averages that were estimated. The impact of some values (that are less than (2.33) means a low impact, from (2.33 - 3.67) means average impact and from (3.67 $-5.00)$ mean a high impact.

Table no. (3-6) shows the accounting averages and the standard deviations for the paragraphs of the variables of the study (the accounting reservation) and such averages are arranged in a descending order as follows:-

\begin{tabular}{|c|c|c|c|c|c|c|}
\hline $\begin{array}{l}\text { The } \\
\text { number }\end{array}$ & Fields & $\begin{array}{l}\text { The } \\
\text { accounting } \\
\text { average }\end{array}$ & $\begin{array}{c}\text { The } \\
\text { standard } \\
\text { deviation }\end{array}$ & $\begin{array}{l}\text { The relative } \\
\text { importance }\end{array}$ & $\begin{array}{l}\text { The } \\
\text { level }\end{array}$ & $\begin{array}{l}\text { The } \\
\text { rate }\end{array}$ \\
\hline 1 & $\begin{array}{l}\text { The hospital is concerned with the } \\
\text { accounting reservation in the } \\
\text { financial statements issued by the } \\
\text { financial and accounting circuit }\end{array}$ & 4.66 & 0.51 & 93.17 & High & 1 \\
\hline 6 & $\begin{array}{l}\text { The accounting reservation provides } \\
\text { a security for protecting any } \\
\text { financial results or financial errors } \\
\text { that may lead to negative results }\end{array}$ & 4.63 & 0.49 & 92.50 & High & 2 \\
\hline 5 & $\begin{array}{l}\text { The accounting reservation protects } \\
\text { the accountants from the danger of } \\
\text { publishing accounting information } \\
\text { that may be wrong in the future }\end{array}$ & 4.46 & 0.66 & 89.17 & High & 3 \\
\hline 2 & $\begin{array}{l}\text { The accounting reservation shall be } \\
\text { executed upon the loss in } \\
\text { comparison to the reservation on the } \\
\text { profits in the financial reports }\end{array}$ & 4.36 & 0.63 & 87.17 & High & 4 \\
\hline 8 & $\begin{array}{l}\text { The accounting reservation protects } \\
\text { the accountants from the legal } \\
\text { accountability to which they may be } \\
\text { exposed }\end{array}$ & 4.36 & 0.62 & 87.17 & High & 4 \\
\hline 7 & $\begin{array}{l}\text { The exaggeration in the accounting } \\
\text { reservation affects the concerned } \\
\text { related parties }\end{array}$ & 4.33 & 0.67 & 86.67 & High & 6 \\
\hline 3 & $\begin{array}{l}\text { The accounting reservation affects } \\
\text { the quality of the accounting } \\
\text { information and the ability to } \\
\text { predict the profits or loss }\end{array}$ & 4.32 & 0.70 & 85.83 & High & 7 \\
\hline 4 & $\begin{array}{l}\text { The accounting reservation is } \\
\text { considered as being a suitable tool } \\
\text { for facing the non-assertion of the } \\
\text { accountants }\end{array}$ & 4.29 & 0.70 & 85.83 & High & 8 \\
\hline & $\begin{array}{l}\text { The independent variable (the } \\
\text { accounting reservation) }\end{array}$ & 4.43 & 0.38 & 88.50 & High & \\
\hline
\end{tabular}

It can be noted from table no. (3-6) that the level of the accounting reservation (the independent variable) was high as 
the value of the accounting average reached (4.43) with a relative importance of (88.50). Also, the level of the paragraphs of the variable was high as the accounting averages were ranging from (4.66 - 4.29). Paragraph no. (1) came in the first place stating that (the hospital concerned) with the accounting reservation in the financial statements issued by the financial and accounting circuit with an accounting average of about (4.66) with a relative importance of (93.17). Paragraph no. (4) came in the last place stating that: (The accounting reservation is considered as being a suitable tool for facing the non-assertion of the accountants) with an accounting average of about (4.29) and a relative importance of (85.83).

2- Analyzing the first affiliated variable (the accuracy of the financial statements):

The accounting averages and standard deviations in table no. (4-6) for the paragraphs of the1- Analyzing the independent variable (the accounting reservation) were calculated and arranged in a descending order as follows:

\begin{tabular}{|c|c|c|c|c|c|c|}
\hline $\begin{array}{l}\text { The } \\
\text { number }\end{array}$ & Fields & $\begin{array}{l}\text { The } \\
\text { accounting } \\
\text { average }\end{array}$ & $\begin{array}{l}\text { The } \\
\text { standard } \\
\text { deviation }\end{array}$ & $\begin{array}{l}\text { The relative } \\
\text { importance }\end{array}$ & $\begin{array}{l}\text { The } \\
\text { level }\end{array}$ & $\begin{array}{l}\text { The } \\
\text { rate }\end{array}$ \\
\hline 8 & $\begin{array}{l}\text { The accounting reservation asserts that } \\
\text { the financial and accounting } \\
\text { information are free of the important } \\
\text { error and away from bias. The } \\
\text { accounting information has the feature } \\
\text { of the accounting reliability }\end{array}$ & 4.60 & 0.53 & 92.00 & High & 1 \\
\hline 1 & $\begin{array}{l}\text { The accounting reservation affects the } \\
\text { accounting reliability of the } \\
\text { information }\end{array}$ & 4.58 & 0.51 & 91.67 & High & 2 \\
\hline 3 & $\begin{array}{l}\text { the accounting reservation decreases } \\
\text { the collapse of the financial markets } \\
\text { through the authentication in the } \\
\text { financial data and information }\end{array}$ & 4.58 & 0.53 & 91.67 & High & 2 \\
\hline 4 & $\begin{array}{l}\text { The accounting reservation helps the } \\
\text { external auditor increasing the } \\
\text { assertion of the financial information } \\
\text { presented by the management }\end{array}$ & 4.54 & 0.56 & 90.83 & High & 4 \\
\hline 7 & $\begin{array}{l}\text { There is a relationship between the } \\
\text { accounting reservation and the } \\
\text { corporate governance which affects the } \\
\text { authentication of the accounting } \\
\text { disclosure in the financial and } \\
\text { accounting reports }\end{array}$ & 4.49 & 0.62 & 89.83 & High & 5 \\
\hline 6 & $\begin{array}{l}\text { The reliability of the accounting } \\
\text { information related to the accounting } \\
\text { reservation affects the continuity of the } \\
\text { private hospitals }\end{array}$ & 4.45 & 0.78 & 89.00 & High & 6 \\
\hline & $\begin{array}{l}\text { Being interested in the accounting } \\
\text { reservation is resulted from the sudden }\end{array}$ & & & & & \\
\hline 2 & $\begin{array}{l}\text { collapses for the international } \\
\text { companies which doubts the } \\
\text { authentication of the accounting } \\
\text { information presented to the related } \\
\text { parties }\end{array}$ & 4.38 & 0.74 & 87.67 & High & 7 \\
\hline 5 & $\begin{array}{l}\text { The accounting reservation affects } \\
\text { upon the accounting disclosure for the } \\
\text { accounting policies upon preparing the } \\
\text { financial statements }\end{array}$ & 4.31 & 0.65 & 86.17 & High & 8 \\
\hline & $\begin{array}{l}\text { The second affiliated variable (the } \\
\text { reliability of the financial statements) }\end{array}$ & 4.49 & 0.34 & 89.85 & High & \\
\hline
\end{tabular}


It can be noted from table no. (4-6) that the level of the first affiliated variable (the reliability of the financial statements) was high as the value of the accounting average reached (4.49) with a relative importance of (89.85). Also, the level of the paragraphs of the variable was high as the accounting averages were ranging from $(4.60-4.31)$. Paragraph no. (8) came in the first place stating that (The accounting reservation asserts that the financial and accounting information are free of the important error and away from bias. The accounting information has the feature of the accounting reliability) with an accounting average of about (4.60) with a relative importance of (93.0). Paragraph no. (5) came in the last place stating that: (The accounting reservation affects upon the accounting disclosure for the accounting policies upon preparing the financial statements ) with an accounting average of about (4.31) and a relative importance of (86.17).

3- Analyzing the second affiliated variable (the fairness of the financial statements):

Table no. (5-6) shows the accounting averages and the standard deviations for the paragraphs of the second affiliated variable (the fairness of the financial statements) and such averages are arranged in a descending order as follows:-

\begin{tabular}{|c|c|c|c|c|c|c|}
\hline $\begin{array}{l}\text { The } \\
\text { number }\end{array}$ & Fields & $\begin{array}{l}\text { The } \\
\text { accounting } \\
\text { average }\end{array}$ & $\begin{array}{l}\text { The } \\
\text { standard } \\
\text { deviation }\end{array}$ & $\begin{array}{l}\text { The relative } \\
\text { importance }\end{array}$ & $\begin{array}{l}\text { The } \\
\text { level }\end{array}$ & $\begin{array}{l}\text { The } \\
\text { rate }\end{array}$ \\
\hline 7 & $\begin{array}{l}\text { the accounting reservation affects upon } \\
\text { the fairness of the marketing values for } \\
\text { the share }\end{array}$ & 4.51 & 0.52 & 90.16 & High & 1 \\
\hline 2 & $\begin{array}{l}\text { The accounting reservation achieves a } \\
\text { suitability among the financial } \\
\text { performance, the fairness of the } \\
\text { information and the presented } \\
\text { financial data }\end{array}$ & 4.50 & 0.50 & 90.00 & High & 2 \\
\hline 5 & $\begin{array}{l}\text { The accounting reservation helps the } \\
\text { administration of the private hospitals } \\
\text { extracting the sound reports of the } \\
\text { external auditor for the financial data } \\
\text { in a true and fair way for the } \\
\text { accounting information }\end{array}$ & 4.48 & 0.56 & 89.52 & High & 3 \\
\hline 6 & $\begin{array}{l}\text { The accounting reservation affects } \\
\text { upon the reevaluation of the assets in } \\
\text { the fair value }\end{array}$ & 4.46 & 0.53 & 89.19 & High & 4 \\
\hline 8 & $\begin{array}{l}\text { The accounting reservation affects } \\
\text { upon the neutrality, authentication and } \\
\text { the accuracy of the fair accounting } \\
\text { information }\end{array}$ & 4.46 & 0.50 & 89.19 & High & 4 \\
\hline 1 & $\begin{array}{l}\text { The accounting reservation achieved } \\
\text { the accounting disclosure for the } \\
\text { financial and accounting information }\end{array}$ & 4.45 & 0.52 & 89.00 & High & 6 \\
\hline 3 & $\begin{array}{l}\text { The accounting reservation affects } \\
\text { upon the fair values in the financial } \\
\text { and accounting statements in hospitals }\end{array}$ & 4.34 & 0.61 & 86.83 & High & 7 \\
\hline 4 & $\begin{array}{l}\text { the accounting reservation affects upon } \\
\text { the disposition of the reports and } \\
\text { financial information to the } \\
\text { comparison, analysis and taking } \\
\text { decisions }\end{array}$ & 4.16 & 0.74 & 83.17 & High & 8 \\
\hline & $\begin{array}{l}\text { The second affiliated variable (the } \\
\text { fairness of the financial statements) }\end{array}$ & 4.42 & 0.37 & 88.38 & High & \\
\hline
\end{tabular}


It can be noted from table no. (5-6) that the level of the second affiliated variable (the fairness of the financial statements) was high as the value of the accounting average reached (4.42) with a relative importance of (88.83). Also, the level of the paragraphs of the variable was high as the accounting averages were ranging from $(4.51-4.16)$. Paragraph no. (7) came in the first place stating that (the accounting reservation affects upon the fairness of the marketing values for the share) with an accounting average of about (4.51) with a relative importance of (90.16). Paragraph no. (4) came in the last place stating that: (the accounting reservation affects upon the disposition of the reports and financial information to the comparison, analysis and taking decisions ) with an accounting average of about (4.16) and a relative importance of (83.17).

\subsection{Secondly: Testing the Hypothesis of the Study}

\section{The First Hypothesis:}

HO: There is no effect having a significant for determining the impact of the accounting reservation in the accuracy of the financial statements in the private hospitals in Jordan.

For testing thishypothesis, the simple decline analysis was used. Table no. (6-6) shows the results of the simple decline analysis and effect of the accounting reservation in the accuracy of the financial statements in the private hospitals in Jordan as follows:

\begin{tabular}{rrrrrrrrr}
\hline Independent Variable & $\mathbf{r}$ & $\mathbf{R}^{2}$ & $\mathbf{f}$ & Sig f & $\boldsymbol{\beta}_{0}$ & $\boldsymbol{\beta}$ & $\mathbf{t}$ & Sig t \\
\hline Reservation Accounting & $\mathbf{0 . 5 6 6}$ & $\mathbf{0 . 3 2 1}$ & $\mathbf{5 5 . 7 0}$ & $* 0.000$ & $\mathbf{2 . 2 5 9}$ & $\mathbf{0 . 5 0 5}$ & $\mathbf{7 . 4 6}$ & $* 0.000$ \\
\hline
\end{tabular}

\section{The Second Hypothesis:}

HO: There is no effect having a significant for determining the impact of the accounting reservation in the fairness of the financial statements in the private hospitals in Jordan.

For testing this hypothesis, the simple decline analysis was used. Table no. (6-6) shows the results of the simple decline analysis and effect of the accounting reservation in the fairness of the financial statements in the private hospitals in Jordan as follows:

\begin{tabular}{rrrrrrrrr}
\hline Independent Variable & $\mathbf{r}$ & $\mathbf{R}^{2}$ & $\mathbf{f}$ & Sig f & $\boldsymbol{\beta}_{0}$ & $\boldsymbol{\beta}$ & t & Sig t \\
\hline Reservation Accounting & $\mathbf{0 . 7 0 6}$ & $\mathbf{0 . 4 9 9}$ & $\mathbf{1 1 7 . 4 2}$ & $* 0.000$ & $\mathbf{1 . 3 4 4}$ & $\mathbf{0 . 6 9 5}$ & $\mathbf{1 0 . 8 3}$ & $* 0.000$ \\
\hline
\end{tabular}

\section{Results and Recommendations}

\subsection{Results}

After analyzing the results of the data of the study sample and testing the hypotheses of the study, the results of the study can be summarized as follows:

1. There is an effect of a statistical significance (for the first hypothesis) for the effect of the accounting reservation in the accuracy of the financial statements in the private hospitals in Jordan as the value of the two variables reached (0.566) and this value is considered as having a statistical significance as the value of $(F)$ that was calculated and reached (55.70) has a statistical significance with a level of (0.000) and such level is less than $(5 \%)$. This result indicates to the effect of the accounting reservation in the reliability of the financial statements in the private hospitals in Jordan.

2. The values of the factor ( $($ ) shows the effect of the accounting reservation in the accuracy of the financial statements in the private hospitals in Jordan in the decline model that was concluded as the value of this effect reached (0.505).

3. Also, the value of (t) shows the written importance of the factor ( $(3)$ that was concluded as the values of the significance level that reached (0.000) for the variable of the accounting disclosure was less than (5\%), so the values of the factors that was concluded are considered as being of a great importance in the decline model.

4. The values of $\left(\mathrm{R}^{2}\right)$ indicate to the difference percentage of the affiliated variable that can be interpreted through the independent variable. This percentage reached (32.1\%) and it shows how the independent variable is able to predict the affiliated variable.

5. By such result, the zero hypothesis of the study shall be rejected and the alternative shall be accepted; i.e. there an effect of the accounting reservation in the accuracy of the financial statements in the private hospitals in Jordan.

6. There is an effect of a statistical significance (for the second hypothesis) for the effect of the accounting reservation in the fairness of the financial statements in the private hospitals in Jordan as the value of the two 
variables reached (0.706) and this value is considered as having a statistical significance as the value of $(\mathrm{F})$ that was calculated and reached (117.42) has a statistical significance with a level of $(0.000)$ and such level is less than $(5 \%)$. This result indicates to the effect of the accounting reservation in the fairness of the financial statements in the private hospitals in Jordan.

7. The values of the factor (B) shows the effect of the accounting reservation in the fairness of the financial statements in the private hospitals in Jordan in the decline model that was concluded as the value of this effect reached (0.695).

8. Also, the value of (t) shows the written importance of the factor $(B)$ that was concluded as the values of the significance level that reached (0.000) for the variable of the income administration was less than (5\%), so the values of the factors that was concluded are considered as being of a great importance in the decline model.

9. The values of $\left(R^{2}\right)$ indicate to the difference percentage of the affiliated variable that can be interpreted through the independent variable. This percentage reached (49.9\%) and it shows how the independent variable is able to predict the affiliated variable.

10. By such result, the zero hypothesis of the study shall be rejected and the alternative shall be accepted; i.e. there an effect of the accounting reservation in the fairness of the financial statements in the private hospitals in Jordan.

11. The accounting reservation affects the accuracy and the fairness of the financial statements in the private hospitals in Jordan.

\subsection{Recommendations}

After analyzing the hypotheses of the study related to the effect of the accounting reservation in the reliability and the fairness of the financial statements in the private hospitals in Jordan and for achieving these matters, the researcher is recommended by the following:

1. Enhancing the positive results shall supposedly increase the interest in the accounting disclosure.

2. The accounting reservation affects the fairness of the financial statements in the private hospitals in Jordan and in other sectors.

3. The necessity of expanding the society of the study in the coming studies as it shall not be restricted to the sector of the private hospitals in Jordan, but exceeding to the governmental hospitals in Jordan and other sectors for including (the industrial sector, universities, insurance, communications and other sectors).

4. The positive results show the accounting reservation upon the accounting and financial information as of the reliability and the fairness

5. All sectors in their different types and business must apply the policy of the accounting reservation.

6. Increasing the awareness of the employees working in the financial circuits and the accounting departments of the importance of the accounting reservation.

\section{References}

Abd Elmageed, Hamida Mohamed. (2013). Measure the level of accounting reservation and the factors influencing it in the financial reports of insurance companies Arabia. Accounting and Auditing Journal (AUSAA), 1(2), the University of Beni Suef - Egypt, (on-line) - http://www.google.com.-.

Abu Jarad, Recep Hsaid Mahmoud. (2015). The Relationship Between the Reservation in Accounting Policies and Corporate Governance and their Impact on Disclosure Quality of the Financial Statements of Local Banks Listed in Palestine Exchange. Master Thesis, Faculty of Commerce, Accounting and Finance Department, Graduate Studies, Islamic University, Gaza - Palestine, (on-line) - http://www.google.com.

Al-Sakini , Al-Awawdeh , Hanan. (2015). The Effect Accounting Conservatism and its Impact on the Fair Value of the Corporation: Empirical Study on Jordanian Puplic Joint-Stock Industrial Companies. International Journal of Business and Social Science, 6(7), July (2015), Isra University , Amman - Jordan "(on-line). [Online] Available: http://www.google.com.

American Hospital Association. Chart of Accoubts for Hospitals. (Chicago : A.H.A. 1976 : 1978 (p-5-13), USA.

Chung, Hyeesoo Hyun \& WynnN, Jinyoung P. (2008). Managerial Legal Liability Coverage and Earings Conservtism. Journal of Accounting and Economics, 46(1), 135 -153 - USA, "(on-line). [Online] Available: http://www.sciencedirect.com. 
Ebaid, Ibrahim Sayed. (2010). The role of institutional investors in increasing the degree of accounting reservation in the financial statements published: the study of the theory and the field of companies listed on the Saudi Stock Market. Faculty of Commerce, Department of Accounting, University of Tanta - Egypt, (on-line) http://www.google.com.

Elkotyn , Khaled \& Aljumaili , Ahmed. (2014). Accounting Conservatism and its Impact on the Forecasting Financial Failure in Industrial Companies Listed on the Amman Stock Exchange an Analytical Study. Research Journal of Finance and Accounting, ISSN 2222-1697 (paper) ISSN 2222-2847(online), 5(2)1, Department of Accounting, Faculty of Economics and Administrative Sciences, Zarqa University, Zarqa - Jordan "(on-line). [Online] Available: http://www.google.com.

Hamdan, Mohammed Allam Mousa. (2011). The impact of the accounting reservation in improving the quality of financial reporting: A Case Study of a Public Shareholding industrial companies of Jordan. Journal of Management Science, 38(2), the Scientific Research / University of Jordan, Amman - Jordan, (on-line) http://www.google.com.

Hamdan, Mohammed Allam Mousa. (2012). Factors affecting the degree of accounting reservation in the preparation of financial reports: Evidence from Jordan's external auditor. Jordan Journal of Business Management, 8(1), Scientific Research, University of Jordan, Amman - Jordan, (on-line) - http://www.google.com.

Hamza, Mohiuddin. (2009). the entrance of accounting theory. Dar Wael for Publishing and Distribution, Second Edition, Amman - Jordan.

Hanan, Radwan sweet. (2000). Financial Reporting (Basis of preparation, presentation and analysis). University House, Faculty of Commerce, Ain Shemesh University - Egypt.

Hussein, Magda Ezzat. (2015). The Impact of Reciprocal Relationship between concentrated ownership structure and conservative accounting on Institutional performance for corporations in the Light of the Economic and Political Conditions in Egypt: An Empirical Study. Accounting and Auditing Journal (AUSAA), II (I), (2014), the University of Beni Suef - Egypt, (on-line) - http://www.google.com.

Jaggi , P , \& Xin , H. ( 2014). Accounting Conservatism and Management Earnings Forecast. [Online] Available at SSRN: http://www.ssrn.com/abstract=2246168.

LaFond, R \& R , Watts. (2008). The Information Role of Conservation. The Accounting Review, 83(2), P. 447 - 478. (on-line). [Online] Available: http://www.google.com.

Matar, Mahdm Attia and Hayali, Walid Naji al-Rawi, sentenced Ahmed. (1996). accounting theory and the information economy. Dar nostalgia for publication and distribution, the first edition, Amman - Jordan.

Najjar, Jamil Hassan. (2014). Measuring the Level of Accounting reservation in Financial Statements and Reports and Its Effects On the Share Market Value. Balqa for Research and Studies, 17(2), Al Quds Open University, Gaza - Palestine, (on-line) - http://www.google.com.

Suas , S. (1997). The Conservatism Principle and The Asymmetric Timeliness of Earnings. Journal of Accounting \& Economics, 24, 3-37.

Youssef, Ali. (2012). Factors affecting the degree of accounting reservation in the preparation of financial reports: Evidence from Jordan's external auditor. Journal of the University of Damascus Economic and Legal Sciences, 28(I), Faculty of Economics - Accounting Department - University of Damascus - Syria, (on-line) http://www.google.com. 